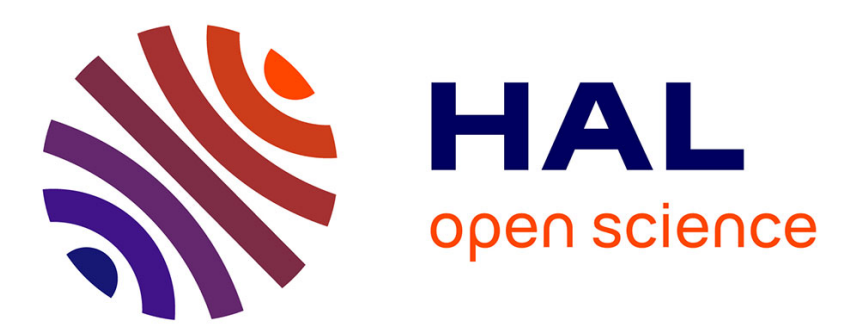

\title{
The oligolectic bee Osmia brevis sonicates Penstemon flowers for pollen: a newly documented behavior for the Megachilidae
}

James Cane

\section{- To cite this version: \\ James Cane. The oligolectic bee Osmia brevis sonicates Penstemon flowers for pollen: a newly doc- umented behavior for the Megachilidae. Apidologie, 2014, 45 (6), pp.678-684. 10.1007/s13592-014- 0286-1 . hal-01234768}

\section{HAL Id: hal-01234768 \\ https://hal.science/hal-01234768}

Submitted on 27 Nov 2015

HAL is a multi-disciplinary open access archive for the deposit and dissemination of scientific research documents, whether they are published or not. The documents may come from teaching and research institutions in France or abroad, or from public or private research centers.
L'archive ouverte pluridisciplinaire HAL, est destinée au dépôt et à la diffusion de documents scientifiques de niveau recherche, publiés ou non, émanant des établissements d'enseignement et de recherche français ou étrangers, des laboratoires publics ou privés. 


\title{
The oligolectic bee Osmia brevis sonicates Penstemon flowers for pollen: a newly documented behavior for the Megachilidae
}

\author{
James H. CANE \\ USDA-ARS Pollinating Insect Research Unit, Utah State University, Logan, UT 84322-5310, USA
}

Received 7 December 2013 - Revised 21 February 2014 - Accepted 2 April 2014

\begin{abstract}
Flowers with poricidally dehiscent anthers are typically nectarless but are avidly visited and often solely pollinated by bees that sonicate the flowers to harvest pollen. Sonication results from shivering the thoracic flight muscles. Honey bees (Apis) and the 4,000+ species of Megachilidae are enigmatic in their seeming inability to sonicate flowers. The oligolectic megachilid bee Osmia brevis was found audibly sonicating two of its beardtongue pollen hosts, Penstemon radicosus and P. cyananthus. The bees' high-pitched sonication sequences are readily distinguishable from flight sounds in audiospectrograms, as well as sounds that result from anther rasping. Instead, floral sonication by $O$. brevis resembles the familiar sounds of bumblebees buzzing, in this case while visiting $P$. strictus flowers.
\end{abstract}

Apiformes / Megachilidae / buzz pollination / Penstemon / floral sonication / pollen foraging / porose anthers

\section{INTRODUCTION}

The anthers of many species of flowering plants do not freely shed their pollen, but rather dehisce pollen through terminal pores, slits, or valves that serve to limit the pollen accessible to individual foraging pollinators. Dispensing pollen to sequential visitors can enhance pollen dispersal and thus male fitness (Harder and Thomson 1989). The widespread trait is reported from 72 plant families representing about $7 \%$ of flowering plants (Buchmann 1983; De Luca and Vallejo-Marin 2013). A similarly diverse group of bees, most notably the bum-

Electronic supplementary material The online version of this article (doi:10.1007/s13592-014-0286-1) contains supplementary material, which is available to authorized users.

Corresponding author: J. Cane,

Jim.Cane@ars.usda.gov

Manuscript editor Peter Rosenkranz blebees, are known to sonicate these poricidal anthers, as well as cones of introrse anthers, to enhance their acquisition of pollen (Buchmann 1985; Buchmann 1983; De Luca and VallejoMarin 2013).

Such sonication or "buzz pollination" is achieved by rapid contractions of a bee's thoracic flight muscles (King et al. 1996). The sound produced during floral sonication is higher pitched and audibly distinct from that of flight. For bumblebees (Bombus) and large carpenter bees (Xylocopa), most of the sound energy of sonication is in the second harmonic frequency above that of flight sounds (King and Buchmann 2003). The temporal patterning of sonication is also distinctive from that of flight, often consisting of stereotypical pulses or prolonged bouts of buzzing (e.g., Cane and Buchmann 1989).

Multiple representatives of all bee families but the Megachilidae have well-documented abilities to sonicate flowers (Buchmann 1983). 
Only two instances of floral sonication have been reported from the Megachilidae, a large bee family comprising one-fifth of all bee species $(4,125$ described species) (Gonzalez et al. 2012). Neff and Simpson (1988) reported hearing several females of the leaf-cutting bee Megachile mendica Cresson faintly buzzing the porose anthers of Chamaecrista fasciculata Michx. (Fabaceae). This legume is a classic nectarless buzz-pollinated flower that is sonicated loudly by other visiting bees (Thorp and Estes 1975). Dukas and Dafni (1990) mentioned hearing an unidentified Hoplitis species buzzing flowers of Trichodesma in Israel. No other literature reports have been found.

Megachilids do harvest pollen from some flowers with porose anthers. In particular, the nectar-bearing species of Vaccinium (Ericaceae) are worked for pollen by some species of Megachile (Cane et al. 1996) and especially Osmia (Torchio 1990; Rust and Osgood 1993; Cane et al. 1985; Maeta et al. 1990b; Sampson et al. 2004; Stubbs et al. 1997). These megachilids use their legs to stroke or drum the staminal column to release blueberry or cranberry pollen, a foraging behavior likewise employed by the honeybee, Apis mellifera L. (Cane et al. 1993). Several of these Osmia species are even Vaccinium oligoleges (taxonomic pollen specialists) (Cane et al. 1985; Rust and Osgood 1993; Stubbs et al. 1997) despite their apparent inability to sonicate anthers.

Here, I report that a common Penstemon oligolege, Osmia brevis Cresson, regularly sonicates the anthers of at least two of its natural hosts, $P$. radicosus Nelson and $P$. cyananthus Hooker. The first acoustical recordings and audiospectrographs of floral sonication for any megachilid are shown to be similar to sonication of $P$. strictus Bentham by the much larger bumblebee, B. nevadensis Cresson.

\section{MATERIALS AND METHODS}

\subsection{Natural history and foraging observations}

Female $O$. brevis were observed collecting pollen from flowers at two patches of $P$. radicosus growing at the margins of two past wildfire near Tuscarora, Elko County, Nevada USA on June 5-6, 2013. Later, in July, female $O$. brevis also were observed sonicating and their pollen foraging sounds recorded as they visited flowers of $P$. strictus in mountain meadows east of Logan, Utah USA. For comparison, I recorded sounds of the bumblebee $B$. nevadensis sonicating flowers of $P$. strictus in a diverse xeriscape garden in Logan. Plant vouchers were deposited with the Intermountain Herbarium and voucher bees were placed in the collections of the USDA-ARS Pollinating Insect Research Unit, both at Utah State University in Logan.

\subsection{Sound analysis}

Foraging sounds of Osmia and Bombus at Penstemon were recorded outdoors using a handheld digital audio recorder (Model H2, Zoom Corp, Tokyo, Japan). Sounds were amplified on the recorder and exported to a computer as digital files. Sound clips were edited and the displays optimized, then analyzed from oscillograms, audiospectrograms, and Discrete Fourier Transformation (DFT) using RavenPro1.4 software (Bioacoustics Research Program, The Cornell Lab of Ornithology, Ithaca, NY).

\section{RESULTS}

\subsection{Pollen foraging behaviors at Penstemon flowers}

On a calm, quiet morning, ten female $O$. brevis were each followed for ten $P$. radicosus flower visits. They audibly sonicated every one of the 100 visited flowers that were observed; most of the females also carried visible abdominal scopal loads of pale Penstemon-colored pollen as well. In mountain meadows east of Logan, O. brevis audibly sonicated every visited flower of $P$. strictus (no formal sample counts kept) (Online Resource 1). At both species, the sonicating females stood upright on the floor of the floral throat, such that the dorsal surfaces of the bee's thorax were opposite and close to the anther sutures of these nototribic flowers. 


\subsection{Sounds of sonication}

Floral sonication by $O$. brevis consisted of $1-$ 3 trains of brief pulsed buzzes while the bee stands upright in a given Penstemon flower. The acoustic frequencies of their buzzing sounded much higher pitched than their flight sounds (Online Resource 1). The audiospectrograms show distinct differences between flight sound and the intermittent sound pulses produced during floral sonication at Penstemon. Sonication sounds have many more overlying harmonics running into the higher frequencies (Figure 1). From the DFT trace, which plots sound power $(\mathrm{dB})$ against frequency, the dominant sound frequency of $O$. brevis flight was $440 \mathrm{~Hz}$, with slightly smaller peaks at 230, 680, and $913 \mathrm{~Hz}$. The bees' sounds of floral sonication were at higher pitches, the largest peaks being at 1,360 and $1,800 \mathrm{~Hz}$, with the three next largest peaks at 918, 2,300, and 2,700 Hz. A similar dichotomy, but at lower pitches, was evident in acoustical recordings of the much larger $B$. nevadensis as it sonicated flowers of $P$. strictus (Figure 1).

\section{DISCUSSION}

Several species of Osmia, including O. brevis, are oligolectic for Penstemon. Tepedino et al. (2011) reviewed the floral associations of $O$. brevis using published reports and museum collections. They concluded that this specialist visits at least 42 species of Penstemon. No prior report mentions sonication of any Penstemon species (or any other flowering plant) by any Osmia species, however, including $O$. brevis. Sonication of Penstemon by O. brevis is not a novel trait of one population. The behavior was observed for most or all floral visits to two different species of Penstemon that were $400 \mathrm{~km}$ apart. Floral sonication of at least some Penstemon hosts by $O$. brevis appears to be a species-specific trait.

The sound produced during floral sonication by bees is noticeably higher pitched than their flight sounds. For Bombus and Xylocopa, most of the sound energy is reportedly in the second harmonic frequency above that of flight (King and Buchmann 2003); the multiple harmonics above this frequency have less sound energy (De Luca and Vallejo-Marin 2013). Sonication by $O$. brevis was consistent with this pitch difference, its dominant harmonics during floral sonication being threefold higher than those of flight, as revealed by the discrete Fourier transforms. These frequency differences, as well as the temporal patterning of the buzzes (Figure 1), make sonication sounds of $O$. brevis audibly distinct from those of flight. By comparison with audio recordings of Bombus sonicating Penstemon flowers (Figure 1), it seems evident that buzzing sounds produced by $O$. brevis while harvesting pollen from flowers of some species of Penstemon are comparable and so generated by flight muscle contractions as well.

Both $O$. brevis and the pollen wasp Pseudomasaris vespoides remove pollen from anthers of some Penstemon species by a second mechanism, anther rasping. The wasp or bee stands beneath the anthers and rapidly rocks to and fro, its punctate thoracic scutum rasping across the teeth of the anther sutures. The sound resembles faint scratching of loosely held paper. Though pulsed, it is audibly different from buzzing and coincides with the visible rocking behavior. Pollen rains out of the vibrated anthers onto the insect's dorsum. For $P$. vespoides visiting flowers of $P$. cyananthus, Torchio (1974) described the behavior as manifesting from the wasp repeatedly head-butting the vertical bend of the staminode (sterile stamen) as it probes past the staminode to reach the nectaries. Torchio (1974) described specialized hair arrays on the thoracic scutum to receive the pollen. Comparable behavior by $O$. brevis was readily seen and heard, but it is rarely mentioned and not yet described in the literature, despite reports that the thoracic scutum of $O$. brevis carries more Penstemon pollen than any other body part (Tepedino et al. 1999). Inasmuch as the much smaller bee visibly worked first one and then the other pair of anthers (Tepedino et al. 1999), anther rasping by $O$. brevis may involve more than a struggle to reach the nectaries. 


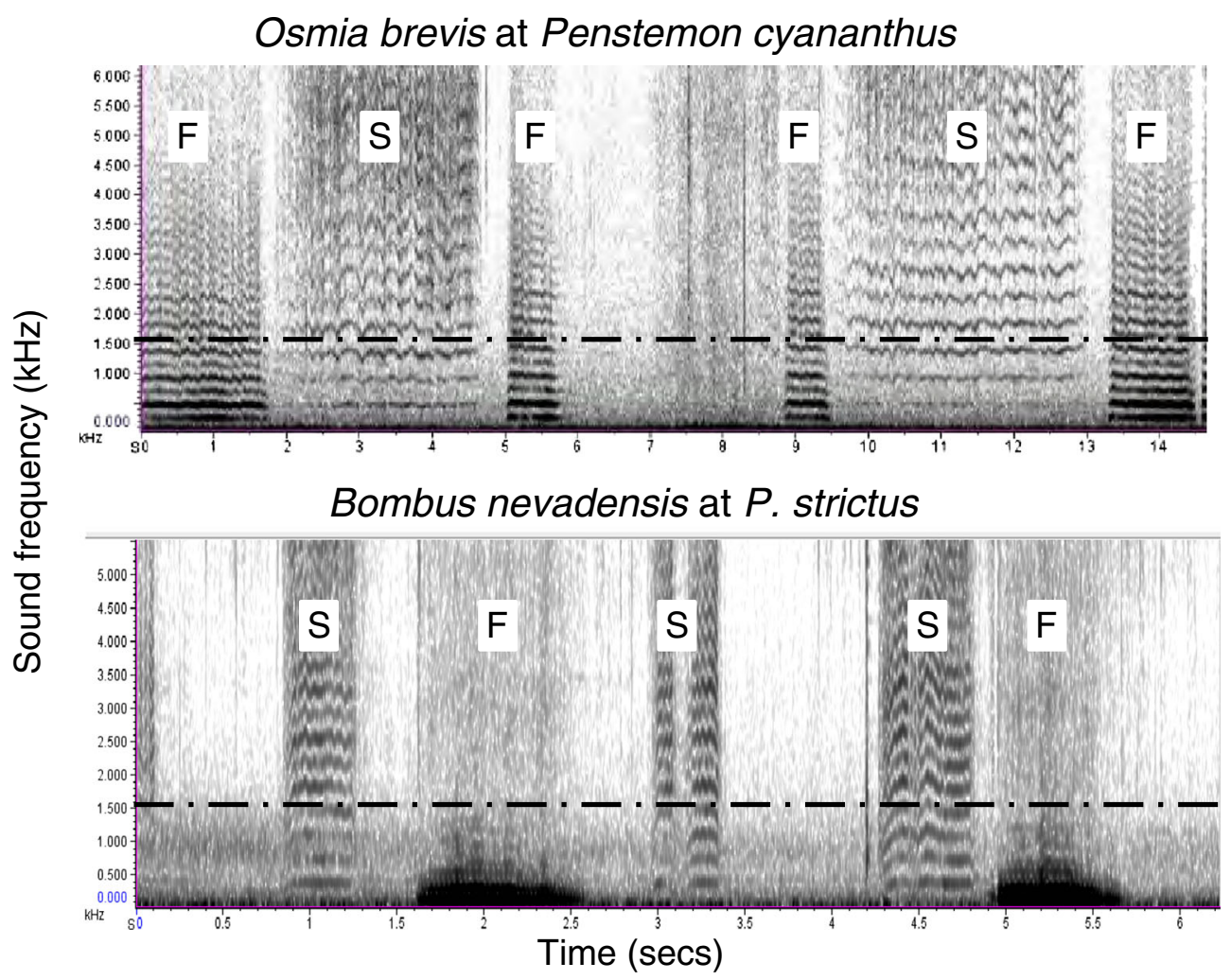

Figure 1. Audiospectrograms from sound recordings of Osmia brevis sonicating flowers of $P$. cyananthus (upper trace) and Bombus sonicating flowers of Penstemon strictus (lower trace). The labels refer to flight $(F)$ and sonication $(S)$ sounds. A dashed reference line is provided at $1,500 \mathrm{~Hz}$.

It seems likely that $O$. brevis will be found sonicating additional Penstemon species. Both of the sonicated hosts reported here present mid-sized blue flowers, common traits for Penstemon species (Nold 1999). Taxonomically, $P$. radicosus belongs to section Penstemon, P. cyananthus to section Glabri. Anther morphologies differ between these two sections; those of $P$. radicosus dehisce along their full length but do not open widely, whereas those of $P$. cyananthus dehisce only from their distal ends (Nold 1999). In the PIRU collections, host labels for $O$. brevis include 16 other Penstemon species in these two sections alone. Close observation of pollen foraging $O$. brevis at additional Penstemon species is needed, distinguishing between floral sonication, anther rasping, or clear absence of these audible foraging behaviors. Less common Penstemon specialists (e.g. O. penstemonis) should be included, as should several other Osmia sometimes common in Penstemon guilds (e.g. $O$. ednae) (Tepedino et al. 1999).

The near absence of floral sonication among species of Osmia is not for the lack of evolutionary opportunities. Admittedly, many of the plant species with porose anthers are tropical (Buchmann 1983), whereas the genus Osmia is Holarctic, largely exclusive of the warm deserts (Michener 2007). Nonetheless, the Ericaceae is rich in species with porose anthers, especially the genus Vaccinium (blueberries, huckleberries, cranberries, etc.). Many of these occur in north temperate regions, where their flowers are sonicated by diverse bee species, especially bumblebees. Species of Osmia are 
often present but rarely common at Vaccinium flowers (reviewed in MacKenzie and Eickwort 1997), foraging for both nectar and pollen (Maeta et al. 1990a; Cane et al. 1985). A few Osmia are even Vaccinium oligoleges (Rust and Osgood 1993; Stubbs and Drummond 1997) and effective blueberry pollinators (Stubbs and Drummond 1997). These Osmia have never been reported to audibly sonicate ericaceous flowers for pollen. Rather, species of Osmia (and Megachile and Apis) dislodge pollen by using their legs to stroke or drum the column of Vaccinium anthers (Torchio 1990; Cane et al. 1985; Cane et al. 1996; Cane et al. 1993), a behavior that precludes a stance for effective sonication.

Some other Holarctic plant genera of other families commonly sonicated by bees include Borago, Dodecatheon, Pedicularis, Polygonatum, Pyrola, Symphytum, and Trichodesma, as well as northern representatives of some mostly tropical buzz-pollinated floral genera (e.g. Chamaecrista and Rhexia). Bumblebees regularly visit and buzz flowers of most of these taxa, often acquiring the pollen ventrally (Corbet et al. 1988; Larson and Barrett 1999; Knudsen and Olesen 1993). Often, they are joined by other bee taxa, but never by cooccurring Osmia (Macior 1964; Macior 1973; Macior 1993; Larson and Barrett 1999; Knudsen and Olesen 1993; Dukas and Dafni 1990). The one exception is Pedicularis semibarbata. Its flowers are not rostrate and therefore do not need to be vibrated to release pollen. It is visited solely by Osmia tristella, which does not buzz its flowers (Macior 1977), consistent with the generalization that Osmia species do not visit classic buzz-pollinated flowers.

The regular sonication of flowers of several species of Penstemon at distant locations by $O$. brevis suggests that this is a species-wide behavioral trait. Was the behavior lost in an ancestral Osmia, only to be derived anew in a single species oligolectic for a plant genus with flowers atypical among buzz-pollinated flowers? Perhaps it is a novel trait of $O$. brevis that has facilitated its radiation onto a number of beardtongue hosts. It nonetheless seems enigmatic that species of
Osmia either eschew visiting flowers with porose anthers altogether (those with anther cones) or harvest their pollen through seemingly inefficient anther stroking using their legs (e.g., Ericaceae). Despite the many studies of Penstemon pollination and the prevalence of Osmia in many of its floral guilds [half the bees collected at Rocky Mountain beardtongues (Clements and Long 1923)], floral sonication by $O$. brevis had not been reported before. It seems reasonable that vibratile pollination by some other species of Osmia also has been somehow overlooked and therefore awaits documentation.

\section{ACKNOWLEDGMENTS}

Research was funded by the Great Basin Native Plant Selection and Increase Project funded through the USDI-BLM Great Basin Restoration Initiative and the USDA-FS Rocky Mountain Research Station. Dr. Noel Holmgren kindly identified the penstemons. Vincent Tepedino and Michael Mesler provided helpful reviews. I dedicate this study to the memory of Philip Torchio, an astute observer of solitary bees.

L'abeille oligolectique Osmia brevis collecte le pollen des fleurs de Penstemon par sonication: un comportement nouvellement mis en évidence pour les Megachilidae

Apiformes / pollinisation vibratile / récolte de pollen / anthères

Die oligolektische Biene Osmia brevis beschallt Blüten der Gattung Penstemon zum Pollensammeln; ein erstmals dokumentiertes Verhalten für Megachiliden

Apiformes / Megachilidae / Vibrationsbestäubung / florale Beschallung / Pollensammeln / poröse Antheren

\section{REFERENCES}

Buchmann, S.L. (1983) Buzz pollination in angiosperms. In: Jones, C.E., Little, R.J. (eds.) Handbook of Experimental Pollination Biology, pp. 73-113. Van Nostrand Reinhold Co, New York

Buchmann, S.L. (1985) Bees use vibration to aid pollen collection from non-poricidal flowers. J. Kansas Entomol. Soc. 58, 517-525 
Cane, J.H., Buchmann, S.L. (1989) Novel pollenharvesting behavior by the bee Protandrena mexicanorum (Hymenoptera:Andrenidae). J. Insect Behav. 2, 431-436

Cane, J.H., Eickwort, G.C., Wesley, F.R., Spielholz, J. (1985) Pollination ecology of Vaccinium stamineum (Ericaceae: Vaccinioideae). Am. J. Bot. 72, 135-142

Cane, J.H., MacKenzie, K., Schiffhauer, D. (1993) Honey bees harvest pollen from the porose anthers of cranberries (Vaccinium macrocarpon) (Ericaceae). Am. Bee J. 133, 293-295

Cane, J.H., Schiffhauer, D., Kervin, L.J. (1996) Pollination, foraging, and nesting ecology of the leaf-cutting bee Megachile (Delomegachile) addenda (Hymenoptera: Megachilidae) on cranberry beds. Ann. Entomol. Soc. Am. 89, 361-367

Clements, F.C., Long, F.L. (1923) Experimental Pollination: An Outline of the Ecology of Flowers and Insects. Carnegie Inst, Washington

Corbet, S.A., Chapman, H., Saville, N. (1988) Vibratory pollen collection and flower form: bumble-bees on Actinidia, Symphytum, Borago and Polygonatum. Funct. Ecol. 2, 147-155

De Luca, P.A., Vallejo-Marin, M. (2013) What's the 'buzz' about? The ecology and evolutionary significance of buzz-pollination. Curr. Opin. Plant Biol. 16, 429-435

Dukas, R., Dafni, A. (1990) Buzz-pollination in three nectariferous Boraginaceae and possible evolution of buzz-pollinated flowers. Plant Syst. Evol. 169, 65-68

Gonzalez, V.H., Griswold, T., Praz, C.J., Danforth, B.N. (2012) Phylogeny of the bee family Megachilidae (Hymenoptera: Apoidea) based on adult morphology. Syst. Entomol. 37, 261-286

Harder, L.D., Thomson, J.D. (1989) Evolutionary options for maximizing pollen dispersal of animalpollinated plants. Am. Nat. 133, 323-344

King, M.J., Buchmann, S.L. (2003) Floral sonication by bees: Mesosomal vibration by Bombus and Xylocopa, but not Apis (Hymenoptera: Apidae), ejects pollen from poricidal anthers. J. Kansas Entomol. Soc. 76, 295-305

King, M.J., Buchmann, S.L., Spangler, H. (1996) Activity of asynchronous flight muscle from two bee families during sonication (buzzing). J. Exp. Biol. 199, 2317-2321

Knudsen, J.T., Olesen, J.M. (1993) Buzz-pollination and patterns in sexual traits in North European Pyrolaceae. Am. J. Bot. 80, 900-913

Larson, B.M.H., Barrett, S.C.H. (1999) The ecology of pollen limitation in buzz-pollinated Rhexia virginica (Melastomataceae). J. Ecol. 87, 371-381

Macior, L.W. (1964) An experimental study of the floral ecology of Dodecatheon meadia. Am. J. Bot. 51, 96-108

Macior, L.W. (1973) The pollination ecology of Pedicularis on Mount Rainier. Am. J. Bot. 60, 863-871
Macior, L.W. (1977) The pollination ecology of Pedicularis in the Sierra Nevada of California. Bull. Torrey Bot. Club 104, 148-154

Macior, L.W. (1993) Pollination ecology of Pedicularis palustris L. (Scrophulariaceae) in North America. Plant Species Biol 8, 35-44

MacKenzie, K.E., Eickwort, G.C. (1997) Diversity and abundance of bees (Hymenoptera: Apoidea) foraging on highbush blueberry (Vaccinium corymbosum L.) in central New York. J. Kansas Entomol. Soc. 69, 185-194

Maeta, Y., Okamura, S., Ueda, H. (1990a) Blueberry pollinators of south-western Japan, with pollinating behaviors of major species. Chugoku Kontyu 4, 1524

Maeta, Y., Okamura, S., Ueda, H. (1990b) Use of the mamekobachi, Osmia cornifrons (Radoszkowski) as a pollinator of blueberries (Hymenoptera, Megachilidae). Unknown 8(32), 33-42

Michener, C.D. (2007) The bees of the world. Johns Hopkins Univ. Press, Baltimore

Neff, J.L., Simpson, B.B. (1988) Vibratile pollenharvesting by Megachile mendica Cresson (Hymenoptera: Megachilidae). J. Kansas Entomol. Soc. 61, 242-244

Nold, R. (1999) Penstemons. Timber Press, Portland

Rust, R.W., Osgood, E.A. (1993) Identification of Osmia kenoyeri and $O$. virga (Hymenoptera: Megachilidae), two blueberry pollinators. Entomol. News 104, 113-117

Sampson, B.J., Stringer, S.J., Cane, J.H., Spiers, J.M. (2004) Screenhouse evaluations of a mason bee Osmia ribifloris (Hymenoptera: Megachilidae) as a pollinator of blueberries in the southeastern United States. Small Fruits Rev. 3, 381-392

Stubbs, C.S., Drummond, F.A. (1997) Blueberry and cranberry (Vaccinium spp.) pollination: a comparison of managed and native bee foraging behavior. In: Richards, K.W. (ed.) Pollination: from theory to practice, pp. 341-344. Acta Horticulturae, Leiden

Stubbs, C.S., Drummond, F.A., Allard, S.L. (1997) Bee conservation and increasing Osmia spp. in Maine lowbush blueberry fields. Northeast. Nat. 4, 133144

Tepedino, V.J., Sipes, S.D., Griswold, T.L. (1999) The reproductive biology and effective pollinators of the endangered beardtongue Penstemon penlandii (Scrophulariaceae). Plant Syst. Evol. 219, 39-54

Tepedino, V.J., Griswold, T.L., Freilich, J.E., Shephard, P. (2011) Specialist and generalist bee visitors of an endemic beardtongue (Penstemon caryi: Plantaginaceae) of the Big Horn Mountains. Wyoming. Western N. Am. Nat. 71, 523-528

Thorp, R.W., Estes, J.R. (1975) Intrafloral behavior of bees on flowers of Cassia fasciculata. J. Kansas Entomol. Soc. 48, 175-184 
Torchio, P.F. (1974) Mechanisms involved in the pollination of Penstemon visited by the masarid wasp, Pseudomasaris vespoides (Cresson). Pan-Pac. Entomol. 50, 226-234
Torchio, P.F. (1990) Osmia ribifloris, a native bee species developed as a commercially managed pollinator of highbush blueberry (Hymenoptera: Megachilidae). J. Kansas Entomol. Soc. 63, 427-436 